BOHUMIL VYKYPĚL

Ústav pro jazyk český AV ČR, Brno

SCOPUS ID 36099272100

e-mail:vykypel@ujc.cas.cz

\title{
Beneš Optát, Petr Gzel, Václav Philomathes, Gramatika česká (1533), ed. Ondřej Koupil. Akropolis, Praha 2019, CIV + ss. 136
}

Ondřej Koupil, přední pracovník na poli starší české gramatografie, pokračuje ve svém badatelsko-editorském úsilí. Po dvou monograficko-kompendiálních pojednáních (Koupil 2015a; 2015b) a třech edicích (Koupil 2003; 2012) vydal nyní první českou gramatiku, vyšlou roku 1533 v poetickém západomoravském městě Náměšti nad Oslavou.

Edice je opatřena cenným úvodem. V něm - po editorově koncízním osvětlení motivace vydání (s. XXVII-XXIX) - nejdříve Petr Voit (s. XXXI-XL) píše o typografických souvislostech náměšt’ské mluvnice: konkrétně o samotné náměšt’ské tiskárně a jejích tiskových písmech a obecně o typografickém novátorství mluvnice, které spočívalo v užití antikvy, korespondující tiskovou formou se zamýšleným humanistickým obsahem gramatiky; obojí - antikvová forma a humanistický obsah - bylo ve své době solitérní.

Ondřej Koupil (s. XLI-LX) pak píše o náměštské mluvnici samotné. Nejdříve pojednává o jejích kontextech, které byly především dvojí, totiž z ciziny vzor soudobých humanistů, filologicky zaujatých, a $\mathrm{z}$ domova tradice překládání bible; tím mluvnice představovala skutečná nova et vetera: první originální a přinejmenším v první polovině českého 16. století ojedinělé, druhé pak tradiční, obvyklé, ale prvním ozvláštněné. Dále píše o autorech mluvnice, jejichž životopisy jsou více či méně nejasné, a o obsahu knihy, k němuž se badatel právě pro kusost biografií autorů musí ve věci autorské intence obrátit především. Nato pokračuje pojednáním o jazykových specifikách náměšt'ské gramatiky, jejichž původ přisuzuje vzniku mluvnice na periferii, mimo pražský mainstream a kterými nejobecněji jsou vstřícnost vůči mluvenému jazyku a nevstřícnost vůči archaismům. Konečně na závěr píše o dalších - pozoruhodně hojných - vydáních mluvnice (včetně onoho nedávno št’astně nalezeného z roku 1543; srov. Koupil 2016) a o vlivu mluvnice, který lze konstatovat jak v dobovém hlavním proudu, jak dosvědčuje odvolávka na mluvnici v úvodu k Melantrichově bibli z roku 1549, tak na dobové periferii, jak dosvědčuje Blahoslavova rukopisná gramatika, vlastně komentář k náměšt’ské mluvnici. Uvážíme-li, že dobová periferie, 
představovaná Blahoslavovou Jednotou bratrskou, se v jazyce později diskrétně stala hlavním proudem a zároveň se ale dobový hlavní proud později neztratil, uvědomíme si, že o zakladatelské roli náměšt’ské mluvnice, kterou svého času snad př́liš důrazně vyzdvihoval Jaroslav Porák (1981; 1985), mluvit skutečně můžeme.

Celý úvod je starosvětsky, leč recenzentovi mile, přeložen do němčiny (s. LXI-CIV) a nato následuje sama edice mluvnice (s. 1-118), doprovozená hustým a hutným komentářem a držící se stejných pravidel jako editorovy edice předchozí (zde znovu vyložených na s. 127-132). Nechybí ani rejstř́ky osob, biblických míst a vykládaných slov (s. 119-125).

Sama náměšt'ská mluvnice byla modernímu čtenáři zpř́istupněna už dříve, ale jen přetiskem, resp. nekomentovaným přepisem (srov. Freidhof 1974), zatímco Koupilova edice je - jak jsme zmínili - opatřena i komentářem. Ovšem hlavní prrínos prrítomného vydavatelského počinu vidíme $\mathrm{v}$ úvodu, který podněcuje $\mathrm{k}$ dalšímu bádání. Při jeho čtení nás napadají různé věci.

Např́iklad poslání Koupilovy úvodní studie (s. LIX-LX) se dá formulovat také podle pražskostrukturalistické zásady o souhře vnějších a vnitřních faktorů při strukturaci a vývoji jazyka i jiných systémů: vnější vliv - v tomto př́padě autorita náměšs’ské gramatiky - se může uplatnit jen tehdy, není-li v rozporu se situací systému - v tomto př́padě $\mathrm{s}$ územ $\mathrm{v}$ daném oboru. Je to myslím další pěkná ukázka deskriptivně-explikativní síly této zásady.

Jiná myšlenka, která nám tane na mysli, je otázka, proč první česká gramatika vznikla na Moravě a ne např́klad v onom pražském hlavním proudu. Mirek Čejka (2009: 93) to sugestivně vysvětloval poukazem jednak na dobový relativně větší intelektuální útlum v Čechách, jednak na „tranzitní“ postavení Moravy mezi kulturními centry vídeňským a krakovským. Ale zdá se, že prozaičtější vysvětlení je, že to byla prostě náhoda, daná tím, že se našel jeden „osvícený“ mecenáš, totiž majitel náměšt’ského panství Václav Meziříčský; když ten umírá, zaniká i krátké náměšstské „kulturní centrum“, jak suše poznamenává Petr Voit (s. XXXI).

A konečně ještě přidejme jeden (maličký) drobek k životopisu jednoho $\mathrm{z}$ autorů gramatiky, Petra Gzela: roku 1502 vedl Matouš Gzel, pražskonovoměstský měšt’an, spor o nemalé peníze s Děpoltem z Lobkovic (srov. Kalousek 1893: 512-513); jestli je to další člen pražské rodiny Gzelů, o níž psal Truhlář (1913: 170-171), ale nevím. Možná právě hádanky životů a motivací našich autorů i jiných dobových intelektuálů (jak se zřejmě ne chudý pražský měšt’an Gzel dostal do Náměště a k sepisování gramatiky?!) mně nakonec přijdou jako to, co je na věci nejpřitažlivější.

\section{Bibliografia}

Čejka M., 2009, Kořeny české gramatografie, v: Pokušeni Jaroslava Kolára. Sborník k osmdesátinám, ed. B. Hanzová, Praha, s. 90-100.

Freidhof G. (ed.), 1974, Beneš Optát, Petr Gzel, Václav Philomates: Grammatyka česká (Die Ausgaben von 1533 und 1588), Frankfurt am Main.

Kalousek J. (ed.), 1893, Archiv český, sv. 12, Praha. 
Koupil O. (ed.), 2003, Matouš Benešovský, zvaný Philonomus: Grammatica Bohemica / Gramatika česká. Knižka slov českých vyložených, Praha.

Koupil O., 2012, Jezuité Drachovius a Steyer gramatiky češtiny, Praha.

Koupil O., 2015a, Grammatykáři. Gramatografická a kulturní reflexe češtiny 1533-1672, 2. vyd., Praha.

Koupil O., 2015b, Grammatyka cžeska. Mluvnice češtiny v 16. až 19. století (katalog výstavy), Praha.

Koupil O., 2016, Druhé vydáni náměštské mluvnice (1543) znovu nalezeno. Podnět k úvahám o hláskosloví, typografii a edični technice, „Česká literatura” LXIV, s. 243-266.

Porák J., 1981, Vytváření normy a její vztah ke kodifikaci v humanistické češtině, „Slovo a slovesnost" XLII, s. 219-227.

Porák J., 1985, Význam a úloha náměštské mluvnice, v: Staršsi české, slovenské a slovanské mluvnice, ed. J. Porák, Praha, s. 7-16.

Truhlář A., 1913, Dodatky a opravy k biografím staršich spisovatelů českých a k starši české bibliografii, „Časopis musea Království českého” LXXXVII, s. 158-190. 